\title{
Effect Of Fermented Cassava Peel (Manihot utilisima) On Performances Of Male Sheep
}

\author{
M Pulungan, I Sembiring, M Tafsin, Hamdan, N D Hanafi \\ Animal Production Program Study, Faculty of Agriculture, University of North Sumatera, \\ Medan 20155, Indonesia \\ E-mail: masrapulungan@gmail.com
}

\begin{abstract}
The experiment aimed to find effect of cassava peel (manihot utilisima) which fermented on performance of local sheep male. The research was conducted at J1. Bunga Rinte, Simpang Selayang, Medan, in October - December 2017 using Completely Randomized Design (CRD) with 4 treatments and 5 replications. The experiment used 20 of local sheep male weaning with initial body weight of $10.18 \pm 1 \mathrm{~kg}$. The treatment provided is P0 (Fermented Cassava peel 0\%), P1 (Fermented Cassava peel 20\%), P2 (Fermented Cassava peel 40\%), and P3 (Fermented Cassava peel $60 \%$ ). The observed of parameters are feed comsumption, average daily gain, feed vonversion (FCR) and income over feed cost (IOFC).

The result of this research indicated that utilization of cassava peel (Manihot utiliima)fermented on performance of local sheep with the average consumption of sheep feed (g/head/day) are: 330.01 ; 364.99; 391.76; and 402.92, average daily gain (g/head/day): 52.86; 71.88; 84.36; and 101.80 and ration conversion: $6.42 ; 5.17 ; 4.78$; dan 4.04 . The conclusion of this research is the higher use of fermented cassava peel the better also the effect on improve of body weight, feed consumption and conversion of local males feed. The highest IOFC value is found in P3 with an average of Rp.276.656,01 during the research.
\end{abstract}

\section{Introduction}

Sheep is one of the livestock ruminants that productivity must be continuously improved in order to meet the food needs of the community. One way that can be done is by utilizing agricultural waste which can have a positive effect on growth, including livestock weight gain. One of the nutritious and easily accessible agricultural wastes is the cassava peel.The use of agricultural waste such as cassava tuber skin will certainly give a positive value to a farm, including the cost of providing feed ingredients.

Nutrient content of cassava peel: PK 4.05\%; SK 27.32\%; LK 0.62\%; and Abu 5,92\% (Laboratory of Nutrition Science and Animal Feed of FP USU Farming Department in Simamora Thesis, [1]. The low nutrient content and the existence of anti-nutrient substance that is cyanide acid (HCN) is the limiting factor of cassava peel usage as animal feed, so it needs further processing for optimum use. Processing is done by fermentation is the use of probiotics in the feed and leave it in a certain time in a closed state.

\section{Materials and Methods}

The research was conducted at J1. Bunga Rinte, Simpang Selayang, From October to December 2017. The Material used were local male sheep as many as 20 heads with an average initial body weight of $10.18 \pm 1 \mathrm{Kg}$. Forage, and concentrated ingredients such as tofu dregs, coconut cake, molasses, ultra minerals, urea, Starbio as fermenters, cassava peel, medicines and clean water.The tools used include: individual cages 20 units, food and drink places, weighing weights of $50 \mathrm{~kg}$ with a weighing capacity of $2 \mathrm{~kg}$ to weigh feed, plastic tarps, drums, jute, plastic rope, grinder, cage cleaning tools, enclosure lighting, stationery, data books and calculators.The research method was experimentally using Completely Randomized Design (RAL) consisting of 4 treatments and 5 replications. The treatment given is the level of giving of Fermented Cassava peel as follows:

$\mathrm{P}_{0}: \quad$ Fermented cassava peel $0 \%$ 
$\mathrm{P}_{1}: \quad$ Fermented cassava peel $20 \%$

$\mathrm{P}_{2}: \quad$ Fermented cassava peel $40 \%$

$\mathrm{P}_{3}$ : $\quad$ Fermented cassava peel $60 \%$

The data obtained will be analyzed, and if the treatment is significantly different $(F \geq 0.5)$ or very real $(\mathrm{F} \geq 0.1)$ then further tested by using Duncan test. The research parameters were Feed consumption, Weight gain, Feed Conversion Ratio,Income over feed cost (IOFC).

\section{Results and Discussion}

\subsection{Feed Consumption (Dry Matter)}

Feed consumption is the ability of cattle to spend a certain amount of feed given in a certain time. Feed consumption is obtained from the difference between the amount of feed given with the amount of residual feed ( $\mathrm{g} / \mathrm{head} / \mathrm{day})$.

Table 1. Average consumption of local male sheep feed during the research ( $\mathrm{g} / \mathrm{head} / \mathrm{day})$

\begin{tabular}{|c|c|c|c|c|c|c|}
\hline \multirow{2}{*}{ Treatment } & \multicolumn{5}{|c|}{ Deuteronomy } & \multirow{2}{*}{ Average \pm SD } \\
\hline & U1 & U2 & U3 & U4 & U5 & \\
\hline P0 & 359.43 & 346.33 & 286.60 & 313.74 & 343.94 & $330.01 \pm 29.48^{\mathrm{b}}$ \\
\hline P1 & 339.34 & 341.36 & 421.13 & 364.25 & 358.87 & $364.99 \pm 33.19^{\mathrm{ab}}$ \\
\hline $\mathrm{P} 2$ & 383.51 & 366.92 & 379.90 & 451.36 & 377.10 & $391.76 \pm 33.89^{\mathrm{a}}$ \\
\hline P3 & 375.95 & 470.89 & 364.19 & 351.17 & 452.37 & $402.92 \pm 54.71^{\mathrm{a}}$ \\
\hline
\end{tabular}

In Table 1 it can be seen that the highest average feed intake is found in $\mathrm{P} 3$ treatment $(60 \%$ Fermented cassava peel) $402.92 \mathrm{~g} / \mathrm{head} / \mathrm{day}$, while the lowest feed intake is in P0 treatment ( $0 \%$ Fermented cassava peel) $330.01 \mathrm{~g} / \mathrm{head} /$ day.

Based on analysis of diversity of feed consumption showed significantly different result $(\mathrm{P}<0,05)$. Where $\mathrm{F}$ arithmetic is greater than $\mathrm{F}$ table, this means the addition of fermented cassava peel in the ration gives a significant different effect on dry matter consumption. This situation is caused by the addition of fermented cassava peel to the level of $60 \%$ in the ration can affect the palatability of feed.

As the research conducted by Oboh [2] that the protein content in cassava peel without fermentation of $8.2 \%$ and increased to $21.5 \%$ after the fermentation process. Both of these are supported by Handayanta's [3] opinion, that the amount of feed consumption is influenced by the palatability and quality value of a feed ingredient.Increased feed consumption up to P3 due to the effect of the addition of microorganisms present in starbio probiotics to feed, the fermentation process that occurs can change the nutrient content in feed such as increased protein levels and reduce crude fiber so that digestive work activities also increase.

This is in accordance with Basri's statement [4] which states that the use of starbio in fermentation can reduce cell wall levels. Lignolytic microbes in starbio help alter lignocellulose bonds so that cellulose and lignin can be released from these bonds by the lignocellulase enzyme.The use of fermented cassava peel in the ration up to the level of $60 \%$ gives a positive influence on the consumption of local rams feed. This suggests that up to that level sheep cattle can utilize the well-fed feed and love the fermented cassava peel provided up to $60 \%$. The process of fermentation is done, in addition to improving the low nutrient content, is also able to reduce anti-nutritional substances (HCN) that exist on the cassava peel. It is safer and easier to digest by sheep. As the research conducted by Purwanti (2007)[7] that the process of washing, steaming and drying cassava skin gives a very significant result that is HCN content of $89.32 \mathrm{mg} / 100 \mathrm{~g}, 16.42 \mathrm{mg} / 100 \mathrm{~g}$ and $8.88 \mathrm{mg} / 100 \mathrm{~g}$ compared with no treatment of $143.3 \mathrm{mg} / 100 \mathrm{~g}$.

\subsection{Increased Body Weight}

Body weight gain is one of the criteria used to measure growth. The weight gain is the difference between the final body weight and the initial body weight divided by the length of the study in units (g/head/day).

Table 2. Mean weight of male local sheep body weight during the research ( $\mathrm{g} / \mathrm{head} / \mathrm{day})$

\begin{tabular}{|c|c|c|c|c|c|c|}
\hline \multirow{2}{*}{ Treatment } & \multicolumn{5}{|c|}{ Deuteronomy } & \multirow{2}{*}{ Average \pm SD } \\
\hline & U1 & $\mathrm{U} 2$ & U3 & $\mathrm{U} 4$ & U5 & \\
\hline $\mathrm{P} 0$ & 54.83 & 57.83 & 37.67 & 66.67 & 47.33 & $52.866 \pm 10.96^{\mathrm{C}}$ \\
\hline $\mathrm{P} 1$ & 65.17 & 68.83 & 62.17 & 75.57 & 87.67 & $71.882 \pm 10.14^{\mathrm{B}}$ \\
\hline
\end{tabular}




\begin{tabular}{lrrrrrc} 
P2 & 85.00 & 112.17 & 73.83 & 73.50 & 77.33 & $84.366 \pm 16.22^{\mathrm{AB}}$ \\
P3 & 114.83 & 115.00 & 101.17 & 98.33 & 79.67 & $101.80 \pm 14.54^{\mathrm{A}}$ \\
\hline
\end{tabular}

Table 2 shows that the average weight gain of the male sheep body during the study was highest at $101.8 \pm 14.54$ (g/ head / day), while the lowest rate was found in treatment P0 which was $52.866 \pm$ 10.96 ( $\mathrm{g} /$ head / day).

The result of the diversity analysis showed that the feeding treatment was very significant $(\mathrm{P}<0,01)$ to the sheep body weight gain during the research. This indicates that there is a factor of feed quality that affects the growth of undigested proteins from the skin of different fermented cassava peel with non fermented cassava peel, where the digestive protein of fermented cassava peel is higher than non fermented cassava peel. Tarmidi [5] adds that one of the most important nutrient feed components for weight gain is protein.

Different weight gain significantly also due to different feed intake. Increased body weight is increasingly influenced by the amount of feed consumed livestock. This suggests that feed on P3 treatment has better nutritional value and digestibility on the skin of fermented cassava bulbs than other treatments so as to give the best response to the growth of sheep. This is supported by Prasojoet al 68] statement that the fermentation process can increase energy and protein content, decrease cyanide content and crude fiber content, and improve digestibility of low-quality foodstuffs. Microbes used in the fermentation process can produce enzymes that will degrade complex compounds to be simpler and synthesize proteins that are the process of enriching protein ingredients.

Table 2 shows that the daily weight gain of sheep in this study has increased in line with the increasing use of Fermented cassava peel. This is because the number of fermented nutrients and proteins in the diet that is increasing greatly affect the growth of livestock as measured by the increase in body weight of sheep. The highest body weight gain was obtained at P3 of $101.8 \mathrm{~g} / \mathrm{head} /$ day. While in previous research [7], who use the feed with cassava tuber skin without fermentation has an average body weight gain of $31.11 \mathrm{~g} / \mathrm{head} /$ day.

\subsection{Conversion feed Ratio}

Conversion of feed is the ratio between the amount of feed consumed at a certain time with the production produced within the same period.

Table 3. Mean conversion of local male sheep feed during the research

\begin{tabular}{lrrrrrr}
\hline \multirow{2}{*}{ Treatment } & \multicolumn{9}{c}{ Deuteronomy } & \multirow{2}{*}{ Average \pm SD } \\
\cline { 2 - 6 } & U1 & U2 & U3 & U4 & U5 & \\
\hline P0 & 6.56 & 5.99 & 7.61 & 4.71 & 7.27 & $6.42 \pm 1.15^{\mathrm{a}}$ \\
P1 & 5.21 & 4.96 & 6.77 & 4.82 & 4.09 & $5.17 \pm 0.98^{\mathrm{ab}}$ \\
P2 & 4.51 & 3.27 & 5.15 & 6.14 & 4.88 & $4.78 \pm 1.04^{\mathrm{b}}$ \\
P3 & 3.27 & 4.10 & 3.60 & 3.57 & 5.68 & $4.04 \pm 0.96^{\mathrm{b}}$ \\
\hline
\end{tabular}

Table 3 shows that the lowest feed conversion rate was found in P3 treatment (60\% Fermented cassava peel) of 4.04, while the highest feed intake was found in treatment of P0 (Fermented cassava peel $0 \%)$ of 6.42 .

The result of the analysis showed that the feeding showed significant effect $(\mathrm{P}<0,05)$ to feed conversion. The results are significantly different due to the results of the analysis of variance of dry matter consumption and the results of daily variance analysis of daily weight gain is also significantly different. This is in accordance with the statement Julianto [8] which states that the conversion of feed associated with weight gain, feed quality and digestibility. This means that the better quality of feed consumed will increase the digestibility of feed and will result in a high body weight increase so that the value of feed conversion becomes low. In this study, in addition to weight gain and feed consumption as a factor of the small value of feed conversion is the quality and nutrition of feed.Where the fermentation process is done to increase the value of nutrients including protein and reduce crude fiber and eliminate levels of anti-nutritional substances $(\mathrm{HCN})$ in the feed.

In the P0 treatment feed, the male local sheep in the study consumed 6.42 gram of dry matter to raise 1 gram of body weight, while in $\mathrm{P} 1$ treatment the feed needed 5.17 gram to raise 1 gram of body weight and so on. The results of this study showed that the best treatment was found in P3 with the lowest conversion value of 4.04. Conversion is an illustration of the efficient use of fodder in 
increasing the weight of livestock. The smaller the feed conversion value, the higher the feed efficiency(Basri,2009)[1].

\subsection{Income Over Feed Cost (IOFC)}

Income Over Feed Cost is one of the ways to calculate simple profits in sheep maintenance.

$\mathrm{IOFC}=(\mathrm{UN} x$ Sheep selling price $/ \mathrm{kg})-($ Total consumption $\times$ Feed price $/ \mathrm{kg})$,

Table 4. Average of male local sheep's income over feed cost (IOFC) during the research (Rp / head)

\begin{tabular}{lcccccc}
\hline \multirow{2}{*}{ Treatment } & \multicolumn{5}{c}{ Deuteronomy } & \multirow{2}{*}{ Average } \\
\cline { 2 - 6 } & $\mathrm{U} 1$ & $\mathrm{U} 2$ & $\mathrm{U} 3$ & $\mathrm{U} 4$ & $\mathrm{U} 5$ & \\
\hline P0 & $190.062,18$ & $139.960,54$ & $148.515,30$ & $178.670,02$ & $168.618,36$ & $165.165,28$ \\
P1 & $172.054,00$ & $182.905,92$ & $157.402,28$ & $201.326,40$ & $238.196,60$ & $190.377,04$ \\
P2 & $228.064,08$ & $310.730,30$ & $194.827,42$ & $188.798,88$ & $205.515,52$ & $225.587,24$ \\
P3 & $317.682,30$ & $311.404,62$ & $277.523,14$ & $269.940,42$ & $206.729,58$ & $276.656,01$ \\
\hline
\end{tabular}

The selling price of sheep is Rp.50,000/kg after the maintenance period. Revenue is obtained from the multiplication of weight gain with the selling price of livestock in the weight of life, while the cost of feed is the amount of costs incurred to produce the weight gain of the agency. This research uses feed with price based on dry material of each kind that is, feed P0 for Rp.1234/kg, feed P1 for Rp.1234/kg, feed P2 for Rp.1254/kg, and P3 feed for Rp.1274/kg.

The average IOFC obtained from the use of cassava tubers in the ration of local rams in the treatment of P0, P1, P2, and P3 respectively; Rp.165.165,28; Rp.190.377.04; Rp.225.587,24 and Rp.276.656,01. The highest average IOFC was found in P3, which was Rp.276,656.01, and the lowest average IOFC was at P0, which was Rp. 165.165,28. This shows the higher the cost of feed, the higher the quality of feed given to livestock thus affecting the increase in body weight in the accompaniment with the higher the acceptance as well.

P3 feed produces the highest IOFC value. This may be due to P3 feed resulting in high sheep PBB and low conversion value, according to Kasim [519], which states that feed consumption, PBB, and feed prices during maintenance can affect the value of IOFC calculations. Treatment with P0 feed resulted in the lowest IOFC due to low PBB and high feed conversion. So the price of cheap feed can not indicate high IOFC, because it is still influenced by feed conversion and PBB.

\section{Conclusions}

The higher use of cassava tubers in rations of up to $60 \%$ further improves livestock performance. The best treatment is found in P3 fermented cassava cassava flour ration with $60 \%$ usage level in ration. The highest IOFC rate is in P3 which is Rp.276.656.01.It is recommended to use cassava peel which is fermented with strabio as local sheep feed ingredient up to $60 \%$ level in ration.

\section{References}

[1] Basri, F. H. M. 2009. Skripsi. Pengaruh tingkat penggunaan ampas tebu fermentasi dalam ransumterhadap performan domba lokal jantan.

[2] Handayanta, E., 2004. Pengaruh Tingkat Penggunaan Ampas Bir Fermentasi dalam Ransum terhadap Performan Sapi Jantan Peranakan Friesian Holstein. Sains Peternakan. Jurusan Produksi Ternak Fakultas Pertanian Universiatas Sebelas Maret. Surakarta. 1(1):1-8.

[3] Hermawan, M. U. 2009. Skripsi. Performa Produksi Domba Ekor Tipis Jantan Pada Berbagai LevelSubtitusi Kulit Singkong Terhadap Rumput Alam. Fakultas Pertanian. Institute Pertanian Bogor.

[4] Julianto, L. T., 2003. Skripsi. Pengaruh Pemberian Urea Molases Blok Sebagai Pakan Suplemen Terhadap Pertumbuhan Pedet PFH Jantan. Fakultas Pertanian, UniversitasSebelas Maret. Surakarta.

[5] Kasim. 2002. Performa domba lokal yang diberi ransum komplit berbahan baku jerami dan onggok yang mendapat perlakuan cairan rumen. Skripsi. Fakultas Peternakan, Institut Pertanian Bogor, Bogor.

[6] Oboh, G. 2006. Nutritive Enrichment Of Cassava Peels Using A Mixed Culture Of Saccharomyces Cerevisae And Lactobacillus Spp Solid Media Fermentation Technique. Electronic J. Biotechnol. 9(1): 46 - 49. 
[7] Purwanti, S. 2007. Pengaruh Perlakuan Terhadap Kadar Asam Sianida (HCN) Kulit Ubi Kayu Sebagai Pakan Alternatif. Karya Tulis Ilmiah. Universitas Hasanudin, Makasar.

[8] Prasojo,W. FM. Suhartati dan Sri Rahayu. 2013. Pemanfaatan kulit singkong fermentasimenggunakan Leuconostoc mesenteroides dalam pakan pengaruhnya terhadap NNH3 dan vfa (in vitro). Jurnal Ilmiah Peternakan 1(1):397-404.

[9] Simamora, N.R. 2011. Skripsi. Pemanfaatan tepung kulit umbi ubi kayu (Manihot utilisima) difermentasi dengan Aspergillus niger pada pakan konsentrat terhadap pertumbuhan domba jantan. Program Studi Peternakan Fakultas Pertanian Universitas Sumatera Utara. Medan.

[10] Tarmidi, A.R., 2004. Pengaruh Pemberian Ransum yang Mangandung Ampas Tebu Hasil Biokonversi oleh Jamur Tiram Putih ( Pleurotus Ostreatus ) Terhadap Performans Domba Priangan. Jurnal Ilmu Ternak dan Veteriner. 9( 3 ) : 157-16 